\title{
Determinants Influencing Performance of Accountants: The Case of Vietnam
}

\author{
Duc Tai Do ${ }^{1}$, Duc Dinh Truong ${ }^{1}$, Manh Dung $\operatorname{Tran}^{2} \&$ Thi Ngoc Lan Nguyen ${ }^{3}$ \\ ${ }^{1}$ University of Labor and Social Affairs, Vietnam \\ ${ }^{2}$ National Economics University, Vietnam \\ ${ }^{3}$ Trade Union University, Vietnam \\ Correspondence: Manh Dung Tran, Room No. 202, A14, Living Quarter of National Economics University, Hai \\ Ba Trung District, Hanoi, Vietnam. Tel: 0947-120-510. E-mail: tmdungktoan@yahoo.com
}

Received: April 12, 2018

Accepted: April 28, 2018

Online Published: May 30, 2018

doi:10.5539/ijef.v10n7p1

URL: https://doi.org/10.5539/ijef.v10n7p1

\begin{abstract}
This study is conducted to investigate the impact levels of determinants on performance of accountants in enterprises in Vietnam. Data were collected from getting 205 questionnaires from firms doing businesses in Vietnam. Based on the data collected, we use Cronbach's Alpha, EFA and run regression model for knowing the impact levels of each independent variable on dependent variable of accountant performance. The results show that four determinants including accounting framework (PL), job satisfaction (HL), supports from firms (HT), confidence of accountants (ST) have positive relationships with accountant performance. Based on the findings, some recommendations are given for improving accountant performances of firms doing business in the context of Vietnam.
\end{abstract}

Keywords: performance, accountants, determinants, Vietnam

\section{Introduction}

Accounting is understood as the collection, processing, examination, analysis and supply of economic and financial information in the form of value, kind and time of work (National Assembly, 2015). Do and Nguyen (2016) pointed out two determinants of Vietnamese accounting standards and tax law affecting performance of accountants at the businesses in the context of Vietnam. They assert that the quality of accounting information available to the manager depends on many factors including performance of accountants. Although they used exploratory factor analysis to determine and quantify the impact of two determinants on performance of accountants at the businesses, this has not quantified the impact of the two determinants and limited research on the sample. In the field of banking, Hoang (2015) analyzed the impact of knowledge management and business ethics on the performance of bank employees.

Through researches in the context of Vietnam and in the world, we see the gaps of the prior studies as (i) focusing only on the impact of Vietnamese accounting standards and tax law on performance of accountants, this is also a limitation because Vietnam's accounting also includes the accounting system, accounting law and accounting regulations; (ii) through running EFA, Structure Equation Modelling (SEM) the determinants that influence the outcome of work in the banking sector. However, the study of the measurement of regression and regression analysis in the field of business accounting in Vietnam has not been conducted.

Based on literature review, we used a qualitative research methodology basing on in-depth interviews with 4 lecturers with extensive experiences in accounting of the National Economics University, University of Labor and Social Affairs and Trade Union University in Vietnam. At the same time, we interviewed 6 experts working as chief accountants and general accountants in Vietnam corporations. The results of the interviews includes performance of accountants, what determinants affect performance of accountants, the role of evaluating results of accounting work for firms. Based on the results of qualitative research and the inheritance of previous studies, we design the model of determinants influencing performance of accountants at the businesses. Moreover, we develop and validate the scales of factors influencing performance of accountants at the businesses, thus providing some recommendations to improve the results of the work done by the accountant at the businesses. 


\section{Research Model}

Based on the results of Kulkarni et al. (2007), Anantatmula (2007), Mulki et al. (2008), Gibs and Ashill (2013) and Hoang (2015); and based on the results of qualitative research through expert interviews, some variables are explained as

\section{Accounting framework}

Accounting in firms is influenced by the Vietnamese legal system, which includes the law on accounting. The system of legal documents on accounting in Vietnam is quite diverse, including Vietnamese accounting standards (VAS), accounting system, accounting law and legal documents such as circulars, regulations. The co-existence of many types of legal documents on accounting in Vietnam illustrates the integration of Vietnam with the common practice of international accounting and demonstrates the state management of accounting. This diversity has affected performance of accountants at the businesses.

Vietnam is one of the countries with having a code law system. Uniformity in accounting work is high, manifested in a unified accounting system, uniform financial reporting format. However, high occupational flexibility is very low.

Accountants in enterprises have limited capacity and qualifications. Meanwhile, legal policies and requirements on accounting are quite diverse, from which the accountant will be confused when combining multiple legal documents simultaneously, and surely affecting the accounting work at the enterprise.

Accountants are familiar with accounting work on the basis of detailed circulars in the accounting work. Therefore, some situations have to apply Vietnamese accounting standards, the accounting staff will face many difficulties because Vietnamese accounting standard has many terms difficult to understand and out of date in comparison with international accounting. This is one of the reasons that affect performance of accountants.

In enterprises in Vietnam, tax law has significant influence on accounting work. Many provisions of tax law are not similar to accounting, on the other hand, businesses are more interested in tax declaration so that accountants with psychological fear of fine but wrong application in the process of handling tasks. So we have

Hypothesis 1: Accounting framework has a positive relationship with accountant performance.

\section{Job Satisfaction}

Deshpande (1996) investigated different aspects of the satisfaction with the work as satisfied with the pay regime; satisfied with the treatment, promotion; satisfied with colleagues; satisfied with the supervisor, manager and general satisfaction with the organization where you work. So we have:

Hypothesis 2: Job satisfaction has a positive impact on accountant performance.

\section{Supports from Firms}

Yavas et al. (2013) confirmed that the support of supervisors and managers helps employees develop more work-related efforts while encouraging positive behaviors and lasting the intention of leaving a job. Professional and soft skills training programs increase the employee's commitment to the organization and reduce their motivation to quit. Organizational support can be provided in a variety of forms such as feedback on job performance, diversity of staff skills, empowerment, labor safety, training, salary and support policies self-control, teamwork environment, reward policy, employment opportunities, promotion opportunities, model leadership, and service technology support. So we have:

Hypothesis 3: Support of the business associates positively with performance of accountants.

\section{Confidence of Accountants}

Many experts believe that the confidence and self-confidence of the accountant are related to the level of education and professional accountant. Previous studies show that accountants with university or higher degrees are more confident and higher self-confidence. This is perfectly suited because accountants gain much knowledge and experience in accounting science as well as soft skills in job processing. Yavas et al. (2013) argued that depression results in reduced fulfillment of assigned tasks and other duties of bank employees. With employees who have a lot of beliefs, they are easy to solve and get out of work depression, so the results of their works are higher than those who lack confidence (Nguyen, 2018). So we have:

Hypothesis 4: The confidence of accountants associates positively with accountant performance.

From the above analyses, we design a research model: 


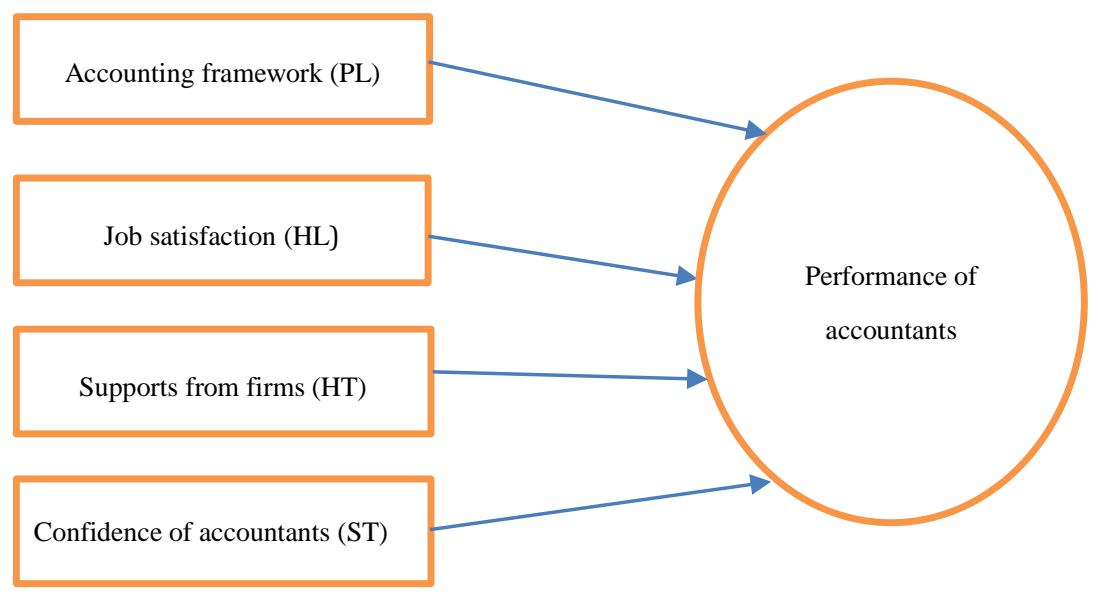

Figure 1. Research model of performance of accountants

\section{Research Methodology}

In order to achieve the objectives of this paper, we based on the theory of previous studies and the results of qualitative research through expert interviews and model analysis. On the other hand, we combined with the inductive method to verify, based on qualitative research results, to adjust and add observation variables to the questionnaire for conducting quantitative research.

Inheriting the results of research by Hoang (2015), Do and Nguyen (2016) and using qualitative research approach through interviews with experts to perform quantitative research, we identify four determinants that affect performance of accountants, i.e. (i) accounting framework, (ii) job satisfaction, (iii) supports from firms; (iv) confidence of accountants. Then, we conducted a questionnaire consisting of 22 observation variables with a 5-point Likert scale. Dependent variable is measured from 1 "not agree" to 5 "fully agree"; Independent variables are measured from 1 "without effect" to 5 "strongly". The method of data collection was done through the survey and subjects are accountants in firms doing business in Vietnam.

We sent 250 questionnaires and received the feedback of 220 . After checking the information on the votes, there are 205 questionnaires with full information for data entry and analysis, the size of this sample is consistent with study of Gorsuch (1983). Among these 205 members, male members accounted for 12.7\%, 179 other women, accounting for $87.3 \%$. Of these, 22 were chief accountants, accounting for $10.7 \%$; 68 were general accountants for $33.2 \%$, accounting staff for $56.1 \%$. $100 \%$ of the respondents had a university degree or above, indicating that the sample was reliable.

We use the EFA analysis and regression model analysis to determine the influence of determinants on performance of accountants at the businesses.

Hoang (2015) stated staff performance is measured by work-related behaviors and results. This result can be quantified in terms of productivity and attitudes to accomplish the task compared to the plan delivered, compared to expectations, relative to peers, or to the underlying role of the individual in the organization. The results of the research work in the field of enterprise accounting are primarily the fulfillment of accounting tasks assigned under Accounting Law No. 88/2015/QH13, namely collecting and processing information, accounting data by object and content of accounting work, according to accounting standards and accounting regime; to inspect and supervise financial revenues and expenditures, obligations to collect and pay debts; to inspect the management and use of assets and sources of asset formation; detecting and preventing acts of violating the legislation on finance and accounting; analysis of accounting information and data; to advise and propose solutions to the management and economic and financial requirements of the accounting units; to supply accounting information and data according to the provisions of law.

In addition, the results of the work done by the accountants are shown by complying with the rules, processes of the organization; long organizational commitment, the rate of resignation is low (Do \& Nguyen, 2016).

Attributes of dependent variable of accountant peformance $(K Q)$ as

KQ1: The fulfillment of accounting tasks assigned under Accounting Law;

KQ2: Compliance with rules, processes of the organization; 
KQ3: Strong organizational commitment;

KQ4: Low resignation rate.

Attributes of independent variable of accounting framework (PL)

PL1: Vietnamese Accounting Standards;

PL2: Business Accounting System;

PL3: Accounting Law;

PL4: Guiding Circulars;

PL5: The complexity of tax law.

Attributes of independent variable of job satisfaction $(H L)$

HL1: Understanding my job requirements;

HL2: Acceptable workload;

HL3: Challenging and interesting jobs;

HL4: Closely related to many colleagues in the company;

HL5: Proud to tell others about the company I am working in.

Attributes of independent variable of supports from firms (HT)

HT1: Company gives me the spirit of responsibilities when working;

HT2: I have the right and necessary information to complete the job;

HT3: I can participate in the training course, provided the necessary documents;

HT4: I am paid by the company for salaries, bonuses and other benefits.

Attributes of independent variable of confidence of accountants (ST)

ST1: The working attitude of the accountant;

ST2: Long time with the company;

ST3: Satisfaction of supervisors with work results;

ST4: Role of Chief Accountant.

\section{Results and Discussions}

\subsection{Quality Scale Testing}

Quality scale testing determinants influencing performance of accountants at the businesses be done by Cronbach's Alpha coefficient and EFA analysis.

Table 1. Results of testing of determinants confidence of scales in the model

\begin{tabular}{lcccc}
\hline \multicolumn{1}{c}{ Determinants } & \multicolumn{2}{c}{ N } & Cronbach's Alpha & $\begin{array}{c}\text { Min - Corrected Item-Total } \\
\text { Correlation }\end{array}$ \\
\cline { 2 - 3 } & Before & After & & 0.858 \\
\hline Accounting framework (PL) & 5 & 5 & 0.873 & 0.570 \\
Job satisfaction (HL) & 5 & 4 & 0.883 & 0.688 \\
Supports from firms (HT) & 4 & 4 & 0.824 & 0.588 \\
Confidence of accountants (ST) & 4 & 4 & & \\
\hline
\end{tabular}

Table 1 shows that all Cronbach's Alpha coefficients of population are above 0.6; all Corrected Item - Total Correlation of observed variables are above 0.3 . So all variables of research model are suitable for next analyses, except HL5 observed variable "I am very proud to tell others about the company I am working in", Cronbach's Alpha's HL5 is bigger than Cronbach's Alpha's HL group factor.

EFA analysis was performed by coefficient deduction method that are Variance Explained, Component Matrix and Rotated Component Matrix.

The results of factor analysis show that $0.5<\mathrm{KMO}=0.886<1$. Barlett's testimony shows sig. $=0.000<0.05$. It means variables in the whole are interrelated (Hair et al., 2006). 
After implementing the rotation matrix, four determinants with factor load factor are greater than 0.5; Eigenvalues are greater than 1 ; the variance explained is $71.24 \%$. It demonstrates that research data analyzing factor discovery is appropriate.

Through the quality assurance of the scale and the test of the EFA model, identify four determinants influence on performance of accountants at the businesses.

Table 2. KMO and Bartlett's test

\begin{tabular}{llr}
\hline Kaiser-Meyer-Olkin Measure of Sampling Adequacy. & .886 \\
\hline Bartlett's Test of Sphericity & Approx. Chi-Square & 1.959815 \\
& df & 136 \\
& Sig. & 0.000 \\
\hline
\end{tabular}

Table 3. Analysis EFA factor of independent variables

\begin{tabular}{|c|c|c|c|c|c|}
\hline \multirow[t]{2}{*}{ Attributes } & \multirow[t]{2}{*}{ Factors after analysis EFA } & \multicolumn{4}{|c|}{ Components } \\
\hline & & 1 & 2 & 3 & 4 \\
\hline PL1 & & .718 & & & \\
\hline PL2 & & .824 & & & \\
\hline PL3 & Accounting framework (PL) & .783 & & & \\
\hline PL4 & & .765 & & & \\
\hline PL5 & & .731 & & & \\
\hline HL1 & & & .828 & & \\
\hline HL2 & Job satisfaction with the work (HL) & & .793 & & \\
\hline HL3 & & & .720 & & \\
\hline HL4 & & & .789 & & \\
\hline HT1 & & & & .758 & \\
\hline HT2 & & & & .754 & \\
\hline HT3 & Supports from firms $(\mathrm{HT})$ & & & .779 & \\
\hline HT4 & & & & .726 & \\
\hline ST1 & & & & & .755 \\
\hline $\mathrm{ST} 2$ & Confidence of accountants (ST) & & & & .788 \\
\hline ST3 & & & & & .837 \\
\hline ST4 & & & & & .781 \\
\hline Initial Eigenvalues & & 6.724 & 2.210 & 2.031 & 1.146 \\
\hline$\%$ of Eigenvalues & & 39.550 & 13.000 & 11.947 & 6.742 \\
\hline
\end{tabular}

\subsection{Regression Model Analysis}

Based on adjusted model after the exploratory factor analysis, we have a multiple regression model:

$$
K Q=\alpha+\beta_{1} P L+\beta_{2} H L+\beta_{3} H T+\beta_{4} S T
$$

Table 4. Model Summary ${ }^{\mathrm{b}}$

\begin{tabular}{cccccc}
\hline Model & $\mathbf{R}$ & $\mathbf{R}^{\mathbf{2}}$ & Adjusted $\mathbf{R}^{\mathbf{2}}$ & Std. Error of the Estimate & Durbin-Watson \\
\hline 1 & $.842^{\mathrm{a}}$ & .708 & .703 & .29012 & 2.289 \\
\hline
\end{tabular}

a. Predictors: (Constant), HL, ST, PL, HT;

b. Dependent Variable: KQ.

Table 5. Anova ${ }^{a}$

\begin{tabular}{llcccc}
\hline & Model & Sum of Squares & Df & Mean Square & F \\
\hline 1 & Regression & 40.896 & 4 & 10.224 & 121.472 \\
& Residual & 16.834 & 200 & 0,084 & \\
& Total & 57.730 & 204 & & \\
\hline
\end{tabular}

a. Dependent Variable: KQ;

b. Predictors: (Constant), HL, ST, PL, HT. 
Table 6. Coefficients ${ }^{\mathrm{a}}$

\begin{tabular}{|c|c|c|c|c|c|c|c|}
\hline \multirow[t]{2}{*}{ Model } & \multicolumn{2}{|c|}{ Unstandardized Coefficients } & \multirow{2}{*}{$\begin{array}{c}\text { Standardized Coefficients } \\
\text { Beta }\end{array}$} & \multirow{2}{*}{$\mathbf{T}$} & \multirow{2}{*}{ Sig. } & \multicolumn{2}{|c|}{ Collinearity Statistics } \\
\hline & B & Std. Error & & & & Tolerance & VIF \\
\hline (Constant) & .975 & .164 & & 5.944 & .000 & & \\
\hline PL & .737 & .039 & .840 & 18.721 & .000 & .725 & 1.379 \\
\hline HT & .049 & .036 & .075 & 1.379 & .016 & .495 & 1.920 \\
\hline ST & .022 & .035 & .026 & .630 & .030 & .866 & 1.155 \\
\hline $\mathrm{HL}$ & .083 & .032 & .023 & 2.579 & .011 & .574 & 1.741 \\
\hline
\end{tabular}

a. Dependent Variable: KQ;

b. Predictors: (Constant), HL, ST, PL, HT.

\section{Results of Table 4, 5 and 6 show that}

Multicollinearity testing: all variance inflation factor (VIF) of independent variables are under 2, so multicollinearity of model is low (Hoang \& Chu, 2008). So, this regression model does not have any violation of the CLRM basic assumption.

Durbin - Watson statistic which is used to test the autocorrelation of residuals presents the model does not violate when using multiple regression method because Durbin - Watson value is 2.289 (in the interval of 1 and 3). In other words, the model is indicated no autocorrelation of residuals (Hoang \& Chu, 2008).

ANOVA testing result: Level of significant (Sig.) $=0.000$ implies that multiple regression model is suitable with data.

Coefficient of $\mathrm{R}^{2}=0.703$, which means $70.3 \%$ of the total variation performance of accountants at the businesses will be explained by the regression model.

Research model result indicates that all independent variables of PL, HL, HT, ST are significant (because Sig. < $0.05)$ to performance of accountants at the businesses.

Determinants impacting on performance of accountants at the businesses in Vietnam are presented in the following standardized regression model:

$$
\mathrm{KQ}=0.840 \times \mathrm{PL}+0.075 \times \mathrm{HT}+0.026 \times \mathrm{ST}+0.023 \times \mathrm{HL}
$$

\subsection{Discussions}

\subsubsection{The Role of Evaluating Performance of Accountants at the Businesses}

It is very important to evaluate performance of accountants at the businesses. The results of the work done by the high staff in addition to better business results for the organization, reduced the rate of dismissal (Ambrose et al., 2008); increase the employee satisfaction with the organization (Tsai \& Huang, 2008). In the field of accounting, the quality of accounting human resources greatly influences the credibility and development of firms (Nguyen, 2014). The achievements of the economy in several decades of innovation through the contribution of people who do accounting, auditing, the results of the work done is one of the indicators that greatly affects the quality of the source accounting manpower (Do \& Nguyen, 2016). Properly evaluating performance of accountants helps the self-employed accountant to have more motivations to work, assert capacity, high responsibility and more job requirements. In addition, it is one of criteria for reorganizing the accounting apparatus effectively as well as meaningful in the existence and development of business.

\subsubsection{Accounting Framework}

This determinant influences performance of accountants at the businesses, so the results are similar to the research of Do and Nguyen (2016). This factor is different from other countries in the world because Vietnamese accounting consists of Vietnamese accounting standards, Vietnamese accounting system, accounting law and other documents such as circulars, regulations on accounting.

\subsubsection{Job Satisfaction}

This factor affects performance of accountants at the businesses. This finding is consistent with studies conducted by Lim and Teo (2010), Aboelmaged and Subbaugh (2012), Gibs and Ashill (2013). The satisfaction with the work indirectly influences the attitudes of accountants to personal results through their own commitments. Gibbs and Ashill (2013) have determined employee satisfaction impacts that increase the performance of employees the Bank conducts direct transactions with clients. 


\subsubsection{Supports from Firms}

A good business only when people are good and the success of the business is usually measured by the quality of human resources, including the person doing the accounting.

A sustainable business must first manage the right people, find the right people, the right role to optimize human resources. Every business has been building support programs to find, develop and retain talent long term. From there, it reduces some costs and helps employees quickly catch up on the pace of their works. Good employee orientation will increase employee satisfactions in the work environment and create positive working attitudes through learning and sharing environments. Following the career-oriented step, senior leaders begin to set long-term goals for employees to achieve. Based on employee transcripts such as work experience, performance, competence framework, employee expectations, or capacity constraints so that leaders can send job assignments to personnel other staff development support for employees is being emphasized. From there, you will find successors for future promotions or appointments.

\subsubsection{Confidence of Accountants}

This determinant affects performance of accountants at the businesses. Accountants in firms believe they can act on their personal convictions to make the right decisions.

Yavas et al. (2013) investigated whether confidence has a positive relationship with job insecurity and job performance outcomes among bank employees working in department directly with the customer or not. The result is that confidence can change that relationship. With employees who have a lot of beliefs, they are easy to solve and get out of work depression, so the results of their works are higher than those who lack confidence.

\section{Conclusions and Recommendations}

Employees of the business, including accounting personnel, are one of the key determinants that determine the development of the business. The better performance of accountants is, the better the business develops (Bontis et al., 2007). On the other hand it reduces the job retrenchment as well as the attachment to the business of the accountant (Ambrose et al., 2008). From the results of the above study, the results of the hypothesis testing are summarized as follows:

\begin{tabular}{lc}
\hline Hypothesis & Results \\
\hline H1: Accounting framework has a positive influence on the results of the work done by enterprise accountants. & Accept \\
H2: Job satisfaction has a positive effect on accountant performance & Accept \\
H3: Support from firms has a positive effect on accountant performance & Accept \\
H4: Confidence of accountants have a positive influence on the results of the work done by businesses accountants. & Accept \\
\hline
\end{tabular}

Based on the findings, some recommendations are given as:

Accounting framework: Currently, the system of legal documents on accounting is quite diverse, so in the process of amending, supplementing or issuing the accounting system by the Ministry of Finance, the content of the accounting regime should be integrated, refer to each accounting standards and accounting law. The system of legal documents on accounting should be supplemented and updated regularly in line with international accounting standards and to strengthen harmonization with international accounting standards to help Vietnamese accountants.

Job satisfaction: Accountants should plan for their job requirements including daily work, monthly work, quarterly work and annual work. In addition, accountants need to understand better and more closely about the rights to work. Moreover, the development of work relationships should be developed as internal relationships with employees, other departments in the company, external relations with tax authorities, suppliers, customers, banks; and accountants need to develop the standard of work requirements with professional competence, work experience, basic knowledge of the business process of the enterprise. Then, accountants will be satisfied with the workload, finding fun in work, in relationships with colleagues and working environment.

Support from firms:

(i) Employee benefits: Welfare solutions have helped businesses maintain high-productivity and well-educated workforces. In addition to annual salary increase, businesses need to develop compensation, promotion. Competent staffs who have achieved high results will be treated satisfactorily and have the opportunity to develop. Reward the things that the accountant has done, building the bonus policy of the business. Enterprises 
should issue and strictly implement policies and programs to support workers such as training programs, development policies, and information sharing.

(ii) Corporate culture: Enterprises and workers work together to create the spirit of solidarity, cooperation between colleagues and employees. Employees need to be reminded of why they need to do their present jobs and what they are doing. Corporate culture, working environment in the business should be clean and transparent. Businesses need to create a corporate culture basing on two to three values that all accountants agree to, or basic rules can help nurture and accelerate the process. Businesses designed their own rules to make the work environment more fun, encouraging accountants to implement creative ideas but legal and beneficial for businesses.

Confidence of accountants: Staff should have confidence in their own abilities and in their works, enhance the spirit of hard work, and meet the wishes of the business. Accountants need to create a trusting relationship with someone who has more experiences in the business that can help them in their works easier, more adaptable to the work environment. Accountants need to create a long-term plan. Develop a long-term strategy with clear objectives and action steps for a period of about one year, then evaluate what has been done and what needs to be improved. The role of chief accountant should be developed and promoted more. The manager should give and receive feedback from accountants, provide a feedback process or a feedback system so that accountants can use confidently and sincerely. Let them know that their opinions are important and most importantly the chief accountant should handle each response. In addition, the chief accountant should empower the employee. The right to decide is a sense of responsibility and ownership that is appealing to build trust. In addition, the head of the accounting department should support staff to learn and develop their skills. This not only creates a motivated team of employees but also fosters professional skills.

\section{References}

Aboelmaged, M. G., \& Subbaugh, S. M. (2012). Factors influencing perceived productivity of Egyptian teleworkers: An empirical stusy. Measuring Business Excellence, 16(2), 3-22. https://doi.org/10.1108/13683041211230285

Ambrose, M. L., Arnaud, A., \& Schminke, M. (2008). Individual moral development and ethical climate: The influence of person - organization fit on job attitudes. Journal of Business Ethics, 77, 323-333. https://doi.org/10.1007/s10551-007-9352-1

Anantatmula, V. S. (2007). Linking KM Effectiveness Attributes to Organizational Performance. The Journal of $\begin{array}{llll}\text { Information and Knowledge Management } & \text { Systems, } & 37(2), & 133-149 .\end{array}$ https://doi.org/10.1108/03055720710759928

Bontis, N., Seleim, A., \& Ashour, A. (2007). The moderating role of Human Capital Management Practices on employee capabilities. Journal of Knowledge Management, 11(3), 31-52. https://doi.org/10.1108/13673270710752090

Deshpande, S. P. (1996). The impact of ethical climate types on facets of job satisfaction: An empirical investigation. Journal of Business Ethics, 15, 655-660. https://doi.org/10.1007/BF00411800

Do, D. T., \& Nguyen, T. H. (2016). The impact of Vietnam accounting standard and tax law on completing work result of firm accountants in Vietnam. Proceedings of Accouting Integration. National Economics University, Part(1), 319-231.

Gerbing, D. W., \& Anderson, J. C. (1998). An Update Paradigm for Scale Development Incorporing Unidimensionality and Its Assessments. Journal of Marketing Research, 25, 186-192. https://doi.org/10.2307/3172650

Gibbs, T., \& Ashill, J. N. (2013). The effects of high performance work practices on job outcomes: Evidence from frontline employees in Russia. International Journal of Bank Marketing, 31(4), 305-326. https://doi.org/10.1108/IJBM-10-2012-0096

Hair, J. F., Anderson, R. E., Tatham, R. L., \& Black, W. C. (2006). Multivariate data analysis. Prentice-Hall, International, Inc.

Hoang, H. Y. (2015). The influences of knowledge management and ethial climate on bank employees's performance. Doctor Thesis, University of Economics Ho Chi Minh City.

Kulkarni, U. R., Ravindran, S., \& Freez, R. (2007). A Knowledge Management Success Model: Theoretical Development and Empirical Validation. Journal of Management Information Systems, 23(3), 309-347. https://doi.org/10.2753/MIS0742-1222230311 
Lim, V., \& Teo, T. (2000). To work or not to work at home: An empirical investigation of factors affecting attitudes towords teleworking. Journal of Managerial Psychology, 15(6), 560-586. https://doi.org/10.1108/02683940010373392

Mulki, J. P., Jaramillo, J. F., \& Locander, W. B. (2008). Effect of Ethical Climate on Turnover Intention: Linking Attitudinal- and Stress Theory. Journal of Business Ethics, 78, 559-574. https://doi.org/10.1007/s10551-007-9368-6

National Assembly. (2015). Accunting law No. 88/2015/QH13.

Nguyen, T. H. N. (2014). The cooperation strengthening between universities and firms in order to increase the quality of accounting human resources training in the direction of integration. Science and Technology Journal, 23, 3-7.

Nguyen, T. M. H. (2018). Impact of working pressure on performance of banking staff in the context of Vietnam. Journal of Economics \& Development, 250, 44-52.

Trong, H., \& Nguyen, M. N. C. (2008). Analysis of research data with SPSS. Hong Duc Publishing House.

Yavas, U., Babakus, E., \& Karatep, O. M. (2013). Does hope moderate the impact of job burnout on frontline bank employee's in-role and extra-role performances? International Journal of Bank Marketing, 31(1), 56-70. https://doi.org/10.1108/02652321311292056

\section{Copyrights}

Copyright for this article is retained by the author(s), with first publication rights granted to the journal.

This is an open-access article distributed under the terms and conditions of the Creative Commons Attribution license (http://creativecommons.org/licenses/by/4.0/). 